\title{
BRUNE OG HVIDE BUDE
}

\author{
Mobiltelefonen som medskaber af budservicemarkedet for illegale \\ rusmidler
}

\section{THOMAS FRIIS SøGAARD}

I de senere år har udbredelsen af nye kommunikationsteknologier forandret måden, illegale rusmidler handles og distribueres på. Handel med illegale rusmidler foregår i stigende grad på online kryptomarkeder (Barratt \& Aldridge 2016), sociale medier (Demant et al. 2019) eller ved hjælp af mobiltelefoner (Salinas 2018; Søgaard et al. 2019). Ifølge May og Hough (2004) har især den øgede brug af mobiltelefoner medført en radikal transformation af det illegale stofmarked på detailniveau og muliggjort mere skjulte og fleksible distributionsmåder såsom narkotikahandel organiseret som budservice (Curtis et al. 2002). Mens traditionelt gadesalg af stoffer ofte foregår inden for et afgrænset geografisk område, hvor køberen kommer til sælgeren, er stofsalg organiseret som budservice kendetegnet ved, at køberen kontakter en sælger, for eksempel pr. telefon, og aftaler et tidspunkt og et mødested, hvor stoffet leveres af sælgeren. Leveringsstedet varierer og kan være køberens hjem, en parkeringsplads, en kontorbygning, en natklub eller et andet givent sted.

Stofsalg organiseret som budservice er ikke et nyt fænomen. Curtis et al. (2002) har for eksempel beskrevet, hvordan udbredelsen af mobiltelefonen samt en intensiveret politiindsats over for gadesælgere havde den konsekvens, at gadehandlen med stoffer på Manhattans Lower East Side op igennem 1990'erne gradvist blev afløst af budservicesalg. Selv om stofsalg via budservice ikke er nyt, peger en del forskning på, at det er en distributionsmodel, som er i vækst. I 2018 offentliggjorde Det Europæiske Overvågningscenter for Narkotika og Narkotikamisbrug en rapport, der viste, at det europæiske kokainmarked synes at undergå en proces, hvor sælgere i stigende grad tilbyder ekstra servicer såsom „hurtig levering overalt og til enhver tid“ (EMCDDA 2018:18). Dette indtryk bekræftes af data fra The Global Drug Survey, som i 2018 spurgte 15.000 stofbrugere på verdensplan, om det var hurtigere at få leveret et gram kokain end en pizza. Mens de hurtigste leveringstider blev registreret i Brasilien og Holland, 
viste undersøgelsen, at kiggede man på by/regionsniveau, blev listen toppet af de tre regioner, som udgør det vestlige Danmark: Region Nordjylland, Region Midtjylland og Region Syddanmark. Her rapporterede cirka 46 procent af de adspurgte, at de kunne få kokain leveret på mindre end 30 minutter (Global Drug Survey 2018). Som dette antyder, er budservice i dag en central distributionsmodel på det danske detailmarked for illegale rusmidler. Billedet bekræftes af en rundspørge foretaget af Jyllands-Posten i 2013, hvor de fleste danske politikredse meddelte, at brugen af „hashbude“ eller „brune bude“ var udbredt (Gustavsen \& Ellegaard 2013). I Danmark har medierne også jævnligt bragt beretninger om „kokainbude“ eller „hvide bude“, hvor stofkøbere kan bestille kokain pr. SMS eller ved et enkelt telefonopkald (J. Søgaard 2018). Mobiltelefoner spiller dog ikke kun en central rolle i koordineringen af illegale penge-for-stof-transaktioner, men også i politiets forsøg på at bekæmpe budservicehandlen. Dansk politi har således udtalt, at de bruger konfiskerede eller aflyttede salgstelefoner indeholdende opkaldsinformation og kundelister til både at opspore sælgere og købere og kortlægge telefonens aktivitetsniveau. Sidstnævnte bruges senere i udmålingen af købernes bødestraf og sælgernes fængselsstraf (Søndberg 2014).

I Danmark findes der kun sparsom forskningsbaseret viden om stofhandel organiseret som budservice. For at skabe en bedre forståelse af budservicemarkedets organisering og dynamikker trækker denne artikel primært på data fra 21 kvalitative interviews med 19 unge mænd, der sælger illegale rusmidler ud fra et deringer-vi-bringer-koncept. Sekundært benytter artiklen også data fra interviews med 28 stofkøbere, som erhverver sig rusmidler fra budservicesælgere. Artiklen argumenterer for, at et fokus på sælgernes salgstelefon og de forskellige måder, denne bliver „,enacted“ (Law 1999), ${ }^{1}$ kan fungere som en prisme, hvorigennem vi kan få indblik i de forskellige og delvis krydsende (fraktale) sociotekniske netværk og praksisser (Mol 2002), som i dag giver form til det mobiltelefonbaserede budservicemarked for illegale rusmidler. Mere præcist belyser analysen, hvordan budservicemarkedet udgøres af forskellige sociotekniske netværk, der skaber fem forskellige versioner af fænomenet salgstelefon, afhængigt af konteksten og hvilke aktører (sælgere, købere, politiet, andre kriminelle) der indgår i netværksformationen. Den første del af analysen fokuserer på mobiltelefonens rolle i sælgernes relation til købere. Her beskrives det, hvordan sælgerne konstruerer mobiltelefonen som både et redskab til intern koordinering af budserviceforretningen og som et kommercielt passagepunkt i relation til stofkunderne. Den anden del fokuserer på mobiltelefonens rolle i sælgernes relation til politiet. Her belyses det, hvordan telefonen artikuleres som et svagt led, der potentielt kan udnyttes af politiet til at optrevle et salgs-/købsnetværk. Den tredje del undersøger salgstelefonens rolle i relationen mellem (konkurrerende) kriminelle stofsælgere. Denne del viser, 
hvordan salgstelefonen både artikuleres som en vare, som når salgstelefonerne og deres kundelister handles mellem stofsælgere, og som et middel til fjendtlig markedsovertagelse, som når kriminelle forsøger at erobre markedsandele ved at stjæle deres konkurrenters salgstelefoner og kundelister. Ved at fremanalysere skabelsen af ovennævnte multiple versioner af sælgernes salgstelefon giver artiklen ikke blot vigtige indsigter i det danske budservicemarked for illegale rusmidler. Den viser samtidig, hvordan nutidens illegale stofmarkeder med fordel kan forstås som sociotekniske netværk, da disse i stigende grad formes af samspillet mellem sociale og teknologiske processer.

\section{Analytisk ramme}

For at fremanalysere de sociotekniske netværk, som i dag giver form til det telefonbaserede budservicemarked for illegale rusmidler, er aktørnetværksteori (ANT) anvendelig. ANT fremhæves ofte som et analytisk perspektiv, der er særligt brugbart til at skærpe forskerens blik for, hvordan sociale ordener (for eksempel illegale stoftransaktioners form) skabes gennem sociotekniske forbindelser og forhandlingsprocesser (Jensen 2005). ANT beskrives også til tider som „,materiel semiotik“" (Law 1999:4). Det skyldes to forhold. Det ene er ANT's grundantagelser om, at mennesker og materielle/teknologiske objekter er gensidigt konstituerende, og at ,ethvert handlingsforløb sjældent kun vil bestå af menneske-til-menneskerelationer [...] eller objekt-til-objekt-relationer, men derimod sandsynligvis vil zigzagge fra den ene til den anden“"(Latour 2005:75). Set fra et sådant perspektiv er ethvert handlingsforløb og praksis (for eksempel stofhandel) et resultat af samspillet mellem en heterogenitet af menneskelige og ikke-menneskelige ,aktører“. I dagligdags sprog og i meget samfundsvidenskabelig teori defineres aktører typisk som menneskelige individer eller kollektiver af individer. I modsætning til dette opererer ANT med en semiotisk og meget åben forståelse af aktøren. En semiotisk aktør, eller ,aktant“ for at bruge ANT's terminologi, kan være en hvilken som helst menneskelig som ikke-menneskelig enhed, der er kilde til handling og får handling fra andre (Jensen 2005). Dette bringer os til det andet forhold. Inspireret af semiotikken er det ANT's ontologiske påstand, at både praksis og objekter er et resultat af, at relationen mellem forskelligartede aktanter ordnes på en bestemt måde. I ANT er det således en vigtig pointe, at ingen aktant har kraft i sig selv, men derimod får handlingskapacitet ved at indgå som et knudepunkt i et netværk, der har opnået en vis stabilitet, og derved skaber effekter og virkeligheder. Deraf begrebet ,aktørnetværk“. Anvender man en sådan relationel tilgang i forståelsen af teknologier, betyder det, at de (for eksempel en mobiltelefon) ikke længere anses som objektlignende ting med en essens eller stabile universelle 
egenskaber. Teknologier anskues i steder som „enacted“, hvilket betyder, at en given teknologis funktion, kapaciteter og effekter er et resultat af dens relationer til andre aktanter i et specifikt netværk (Law 1999; Mol 2002).

Traditionelt har ANT-forskningen været optaget af at kortlægge de ,translationer“, gennem hvilke bestemte aktørnetværk opbygges, og de enkelte aktanter (for eksempel teknologiske objekter) opnår bestemte kapaciteter og funktioner (Gad \& Jensen 2007). I analysen anvender jeg denne tilgang til at vise, hvordan mobiltelefonen i relationen mellem stofsælgere og stofkøbere bliver forsøgt etableret som et „obligatorisk passagepunkt“ (Callon 1986) for penge-for-stof-transaktioner. I en ANT-forståelse kan et obligatorisk passagepunkt forstås enten metaforisk eller konkret som en passage, alle involverede aktører må forholde sig til eller passere (igennem) for at opnå deres mål. I nærværende sammenhæng er målet for stofbrugerne at få adgang til stoffer, mens det for sælgerne er at sælge stoffer. Lidt forenklet kan man sige, at set fra en budservicesælgers perspektiv kører hans forretning optimalt, når mange kunder vælger at benytte netop hans salgstelefonnummer som en passage eller kanal til at få adgang til stoffer. For den enkelte budservicesælger er problemet dog, at han ofte har mange konkurrenter, der alle forsøger at få stofbrugerne i et bestemt lokalområde til at ringe til netop deres salgstelefonnummer. I analysen belyser jeg derfor, hvordan konkurrerende budservicesælgere gør brug af forskellige ,interesse- og indrulleringsstrategier“ (Callon 1986) - såsom at uddele telefonnumre og løbende udsende SMS-reklamer - i forsøget på at vække potentielle kunders interesse og knytte disse til netop deres salgstelefonnummer, som derved kommer til at fungere som det, jeg kalder for et „kommercielt passagepunkt" for køb og salg af stoffer.

Mens et traditionelt ANT-perspektiv primært interesserer sig for, hvordan det lykkes at opbygge nogle sociotekniske aktørnetværk frem for andre, har nyere ANT-tilgange (post-ANT) været optaget af at belyse de praktiske og lokale implikationer af sameksistensen af flere sociotekniske netværk. Centralt i denne nyudvikling er begreberne „performance“ og „enactment" - som på dansk ofte oversættes med „praktiseres“ og „udføres“ eller „gøres“ (Gad \& Jensen 2007) - og begrebet „ontologisk multiplicitet“ (Mol 2002). Mens førstnævnte refererer til, at fænomener ikke eksisterer uafhængigt af de praksisser, hvori de manipuleres og italesættes, er sidstnævnte anvendeligt til at belyse, hvordan forskellige sameksisterende netværksformationer producerer forskellige versioner af det samme fænomen (Law 1999; Mol 2002). Set fra et sådant perspektiv kan den samme teknologi have mange forskellige kapaciteter, betydninger og effekter afhængigt af de forskellige kæder af relationer og praksisser, som den udføres gennem (Mol 2002). I analysen anvender jeg dette perspektiv både til at belyse, hvordan budservicemarkedet for illegale stoffer består af forskellige so- 
ciotekniske netværksformationer, som hver især artikulerer multiple versioner af salgstelefonen (et redskab, et kommercielt passagepunkt, et svagt led, en vare, et middel til markedsovertagelse), og til at vise, hvordan de forskellige versioner af salgstelefonen har en fraktal karakter. Det vil sige, at de forskellige versioner af salgstelefonen ikke er klar adskilte, men derimod delvis krydsende og forbundne, hvilket til tider skaber nye problemer for stofsælgerne.

\section{Baggrund}

I Danmark opstod det første offentligt kendte eksempel på illegal stofhandel organiseret som budservice i København i de tidlige 2000'erne (Dahlin 2015). Siden da har budservicemodellen spredt sig til mange andre større og mellemstore danske byer (Søgaard et al. 2019; Søgaard 2019a, 2019b). Fremkomsten og spredningen af budservicemodellen skyldes særligt to udviklinger. Den ene er udbredelsen af mobiltelefonen som allemandseje, hvilket har gjort det muligt for illegale stofsælgere og -købere at kommunikere mere skjult og lettere koordinere mødesteder på tværs af tid og rum. På den anden side kan udbredelsen af budservicemodellen også ses som det illegale stofmarkeds reaktion på en række politiske og politimæssige tiltag. I 2003 lancerede den daværende regering handlingsplanen „Kampen mod narko“ (Indenrigs- og Sundhedsministeriet 2003), som blandt andet havde til formål at intensivere politiindsatsen over for salg af stoffer på gaden. I årene forinden havde regeringen også skærpet lovgivningen, så det blev lettere at straffe personer for salg af meget små mængder illegale rusmidler, den såkaldte „pusherlov“ i 1996. Ligeledes vedtog man i 2001 den såkaldte ,hashklublov“. Sidstnævnte betød, at politiet nu fik øgede administrative beføjelser til at udstede forbud mod, at personer besøgte eller tog ophold i lokaler (typisk lejligheder), som politiet mistænkte blev brugt til salg af illegale rusmidler. Politiets forsøg på at slå hårdt ned på den åbenlyse gadehandel og de såkaldte hashklubber betød imidlertid ikke, at det illegale stofmarked forsvandt. Tværtimod førte det til en række transformationer på detailniveau. Mens nogle gadesælgere flyttede sig til steder i byen, hvor der var mindre politi, begyndte andre at sælge på mere diskrete måder, for eksempel at sælge fra biler eller at tilbyde bududlevering (Frank 2008).

I sammenligning med traditionel gadehandel er stofbudes salg af illegale rusmidler sværere at opdage for politiet (Barendregt et al. 2006; T. Søgaard 2018). En grund til dette er, at stofhandel organiseret som budservice ikke er statisk knyttet til et bestemt geografisk sted, hvilket gør den mindre synlig. Frem for at hænge ud på gadehjørner eller i lejligheder er budservicesalg karakteriseret ved en høj grad af fleksibilitet, hvilket betyder, at budene konstant er i bevægelse 
fra én køber til en anden eller fra et stoflager til køberne. For at fange sælgerne kan politiet således ikke længere nøjes med blot fysisk at overvåge et mindre antal kendte handelssteder. Politiet må derimod enten følge buddet rundt $\mathrm{i}$ byen, prøve at holde øje med en underskov af mindre handelssteder eller forsøge at opspore og aflytte telefonnummeret, som sælgeren anvender i kommunikationen med køberne.

\section{Metode og data}

Artiklen er primært baseret på data fra 21 kvalitative interviews med 19 aktive budservicesælgere i alderen 17 til 22 år. Interviewene blev foretaget som del af et større forskningsprojekt, ${ }^{2}$ der har til formål at undersøge, hvordan unge mænd med etnisk minoritetsbaggrund oplever dansk politi. I dette studie interviewede vi (i 2016 og 2017) 100 unge minoritetsmænd, der alle boede i en større dansk by, som her benævnes Telborg. De oprindelige interviews handlede primært om de unges oplevelser og syn på politiet (Haller et al. 2020). I interviewene blev det klart, at flere af deltagerne var involveret i narkotikahandel. Da der i Danmark kun findes meget sparsom forskning om handel med illegale rusmidler, besluttede vi derfor at invitere disse deltagere til at blive geninterviewet, nu med fokus på deres salgsaktiviteter. Disse andenrundeinterviews varede mellem en og to timer, og i interviewene blev der anvendt en semistruktureret interviewguide. De 19 unge mænd, som tog del i andenrundeinterviewene, var alle vokset op i det samme udsatte boligområde, som er karakteriseret ved relativt høje arbejdsløsheds- og kriminalitetsrater. De unge mænd beskrev sig selv som havende palæstinensisk, somalisk, tyrkisk, irakisk og kurdisk kulturel baggrund. 10 af deltagerne var officielt arbejdsløse, to gik på gymnasiet, fem gik på teknisk skole, og to arbejdede i dagligvareforretninger. Mens 12 af deltagerne forklarede, at de penge, de tjente ved stofhandel, udgjorde et supplement til deres kontanthjælp eller SU, forklarede syv, at salg af stoffer var deres primære eller eneste indtægt.

Andenrundeinterviewene blev lavet over en periode på et halvt år, og enkelte nøgleinformanter blev interviewet flere gange. Inden interviewene blev deltagerne grundigt informeret om studiets nye formål, og at deres deltagelse var frivillig og anonym. Interviewene var designet til at undersøge følgende temaer: motiver for og veje ind i stofhandel, den sociale og tekniske organisering af budservicebaseret stofhandel, sælgernes salgspraksis og mobiltelefonteknologiens rolle i dette. Vigtigheden af mobiltelefonen i deltagernes stofhandel blev understreget af, at flere interviews midlertidigt måtte afbrydes, så deltagerne kunne besvare kundeopkald på deres salgstelefoner. Disse episoder og interviewene viste, at sælgerne udelukkende gjorde brug af meget simple mobiltelefoner uden internet, 
GPS eller Bluetooth i deres kommunikation med kunderne. Betydningen af dette vil senere blive uddybet. Databehandlingen tog udgangspunkt i en grounded theory-tilgang (Strauss \& Corbin 1997), hvor alle interviewene først blev grovkodet induktivt ud fra spirende temaer såsom ,,veje ind i stofhandel“, „den praktiske brug af salgstelefonen“, „,sikkerhed og politi“, „rekruttering af og interaktion med kunder“, „,sociale netværk“, „SIM-kortet“ og „,andre kriminelle“. I forbindelse med denne artikel blev de oprindelige koder genbesøgt og genkodet nu med et særligt fokus på mobiltelefonteknologiens rolle i sælgernes stofhandel. Inspireret af Latours metodiske slogan om, at vi skal „følge aktørerne“ (Latour 2005:12), havde andenrundekodningen til formål at identificere mønstre og fortætninger i de forbindelser, som skabes mellem salgstelefonen, sælgerne og andre relevante aktører. I den efterfølgende analyse præsenteres de mest dominerede sociotekniske fortætninger, og der argumenteres for, at disse artikulerer fem forskellige versioner af fænomenet stoftelefon, som tilsammen er med til at give form til det telefonbaserede budservicemarked for illegale rusmidler.

For at nuancere nogle af artiklens analyser trækker jeg i mindre grad også på data fra et nyere studie (2018-2019), som undersøger budservicefænomenet set fra et køberperspektiv (Søgaard 2019a, 2019b). Dette studie består af interviews med 28 stofbrugere, som alle har førstehåndserfaring med at købe illegale rusmidler fra budservicesælgere. I køberstudiet blev der også indsamlet 69 SMSbaserede reklamebeskeder sendt fra budservicesælgere til "stofkøbere" som en måde at promovere deres forretning og produkter på. Alle deltagere, steder og reklamebeskeder er anonymiserede.

\section{Relationen til køberne: et koordineringsredskab og kommercielt passagepunkt}

I det følgende beskrives det, hvordan mobiltelefonen skabes både som et redskab til intern koordinering og som et kommercielt passagepunkt for kundernes erhvervelse af stoffer. Inden da giver jeg et kort rids over, hvordan sælgernes budserviceforretning er organiseret.

Flere sælgere beskrev, hvordan deres stofsalg delte lighedstræk med taxaarbejde og pizzaudlevering:

Det er det samme som en taxachauffør. Ens telefon ringer. Du skal ud og mødes med folk. Du skal være der om 10 minutter, så du har meget travlt. Du skal ikke køre dem et sted hen. Du skal ud og give dem noget. Og så får du penge (Asharf).

Sælgerne afviste at være del af en bande. I stedet forklarede de, at de fleste lokale budserviceforretninger var drevet af mindre grupper - eller entreprenørteams 
- bestående typisk af to til fire personer, som arbejdede sammen. En grund til, at budsælgerne finder sammen i mindre teams, er, at de ofte arbejder under tidspres, da deres forretningskoncept bygger på hurtig levering af stoffer til kunderne:

Du skal holde dine tider, det er meget vigtigt. Det er ligesom, når du bestiller en pizza, og du er megasulten. Du [kunden] gider ikke vente en time, vel (Hamsa).

I skabelsen af en succesfuld budserviceforretning indgår mange forskellige sociotekniske praksisser. Ikke blot bruger sælgerne biler og i mindre grad scootere til at bringe stoffer ud til kunderne. Mobiltelefonen spiller også en central rolle i den interne koordinering og i selve opbygningen af en budserviceforretning. I forhold til den interne koordinering beskrev sælgerne, at de fleste teams var karakteriseret ved en vis arbejdsdeling. Mens ejeren eller ejerne af salgstelefonen ofte passer salgstelefonen, tit fra deres hjem eller andet sted, og besvarer opkald eller SMS'er fra kunderne, efterhånden som de tikker ind, har en anden (buddet) ansvaret for at køre kurerbilen med stofferne ud til kunderne. I de tilfælde, hvor budserviceforretningen drives af blot to ejere, skiftes de ofte til at passe telefonen og køre ud med stofferne. Denne arbejdsdeling samt det faktum, at kurerbilen ofte er i konstant bevægelse fra én køber til en anden eller fra et stoflager til køberne, har skabt nye behov for både rumlig og tidslig koordinering. Når salgstelefonens ejere modtager et opkald fra en kunde, skal de efterfølgende ringe til buddet for at koordinere dennes rute mest effektivt.

Ud over at mobiltelefonen fungerer som et redskab til intern koordinering, står og falder selve opbygningen af en succesfuld budserviceforretning med sælgernes evne til at konstruere et specifikt telefonnummer som et attraktivt ,passagepunkt“ (Callon 1986) for potentielle købere på jagt efter stoffer. Sagt på en anden måde kan man sige, at for en vordende budservicesælger med adgang til en pålidelig leverandør består opbygningen af en budserviceforretning i to centrale skridt. Det første er, at man anskaffer sig en mobiltelefon og et telefonnummer, der tilsammen kan fungere som en salgstelefon, det vil sige som et bindeled mellem købere og sælgeren. Det næste skridt er, at man skal forsøge at gøre potentielle kunder interesserede $i$ at kontakte og benytte netop dette telefonnummer som en kanal til at få adgang til stoffer. Sidstnævnte kræver meget arbejde, da det telefonbaserede budservicemarked er karakteriseret ved massiv konkurrence mellem mange sælgere. Interviewene med budservicekøbere viste eksempelvis, at de ofte har flere sælgernumre at vælge imellem, når de ønsker at købe stoffer (Søgaard 2019a, 2019b). I forsøget på at gøre potentielle købere interesserede i at kontakte netop deres telefonnummer gjorde sælgerne brug af forskellige interessekonstruktionsstrategier (Callon 1986). Sælgeren Mehmet forklarede eksempelvis, hvordan han sommetider engagerede sig i traditionelt gadesalg ved 
natklubber eller på gaden i forsøget på at rekruttere kunder til sin salgstelefon. Mehmet betonede, at det egentlige formål med disse gadetransaktioner ikke var at sælge stoffer, men derimod at dele sit nummer ud til kunderne, da det kunne skabe en mere varig relation:

Jeg tog ind til byen og tog kontakt til folk, solgte et par poser, gav dem mit nummer, gav mit nummer til ham, til ham, til ham og måske gav dem en gratis smagsprøve, gav nogle flere numre ud ..., og langsomt så starter det, og én ringer: 'Jeg har brug for noget af det gode' (Mehmet).

I tråd med dette forklarede Abdul, at han og hans venner sommetider tog til en park i centrum af byen, som var kendt som et salgssted for illegale rusmidler. Abdul forklarede, at fordi parken var en visitationszone, og politiet derfor kunne visitere alle uden begrundet mistanke, medbragte han og hans venner aldrig stoffer. I stedet medbragte de papirlapper og businesskort med deres telefonnummer, som de delte ud til potentielle kunder:

Du ved, vi har Torveparken. Politiet kan visitere dig uden grund, fordi der bliver solgt mange stoffer der. Så vi tager derned, venter, venter, venter, og når én så kommer hen til dig, så siger du: 'Måske du har brug for et nummer, så du ikke behøver at komme her. Jeg kommer til dig.' Så siger han, 'Ja'. 'Værsgo!' [viser med hånden, hvordan han giver kunden et stykke papir]. Og det er sådan, det starter (Abdul).

Som ovenstående viser, er gadesalg, uddelingen af gratis vareprøver og ,businesskort" til tider instrumentelle i forhold til sælgernes forsøg på at skabe opmærksomhed og konstruere køberinteresse for netop deres salgsnummer. Mobiltelefonen spiller imidlertid også en central rolle i sælgernes forsøg på at transformere købernes indledende interesse til en mere varig tilknytning til et bestemt salgsnummer. En af de strategier, sælgerne bruger til at ,indrullere“ (Callon 1986) køberne i mere varige netværksrelationer, er jævnligt at sende gruppebaserede SMS-reklamer til personer, der tidligere har kontaktet dem og efterspurgt stoffer. SMS-reklamerne indeholder typisk information om sælgerens åbningstider, priser og slagtilbud, og de betoner ofte produkternes kvalitet og sælgernes hurtige leveringstid. Nedenstående er et eksempel på en SMS-reklame:

Så er J-dag lige om hjørnet! Det skal selvfølgeligt fejres! Mine damer og herrer tag godt imod dette LÆKRE TILBUD: $0.5 \mathrm{~g}$ for $400 \mathrm{kr} 1 \mathrm{~g}$ for $700 \mathrm{kr} 1.5$ for $1000 \mathrm{kr}$. Dette er skræddersyet til denne begivenhed, og det kører fra fredag kl: 14 til mandag kl: 7. Glæder mig til at se jer og dele en flaske $ø 1$ med jer!:

Sælgernes brug af SMS-reklamer tjener flere formål, herunder at tilskrive modtageren en rolle som stofkøber og at guide dennes valg. I et budservicemarked med 
mange udbydere kan det, at man løbende rundsender reklamer, være en måde at fastholde kundernes opmærksomhed og tilknytning til et specifikt salgsnummer. I SMS-reklamerne fremhæver mange sælgere derfor også ofte deres brandnavn, da det antages, at køberne nemmere kan huske navne som Cool Style, Den Høje eller Mekaniker Tom frem for et anonymt telefonnummer. Interviewene med køberne viste, at reklamerne kan have en vis effekt på nogle stofbrugeres praksis, derved at det at modtage en SMS-reklame på telefonen kan medvirke til at pirre ens lyst, emotioner og stoftrang:

Jeg er oplevet, at nogle af mine venner, som ryger hash, der har villet holde enten pause eller stoppe helt, og så får de en af de her SMS'er. Det gør simpelthen så meget ved deres abstinenser, og så går de ud og køber kort efter (Jens).

Ovenstående er interessant, fordi det viser, hvordan konstruktionen af salgstelefonen som et kommercielt passagepunkt for penge-for-stof-transaktioner implicerer formationen af en lang række teknosociale og teknoemotionelle relationer, hvor sælgerne, telefonteknologien, køberne, papirlapper/businesskort, gratis stofprøver, reklamer, brandnavne og kropslige emotioner alle kommer til at fungere som aktanter, der tilsammen skaber bestemte praksisser.

\section{Relationen til politiet: et potentielt svagt led}

I takt med at telebaserede og digitale kommunikationsteknologier er blevet centrale i udøvelsen af kriminalitet, er de også blevet mål for politiet. Politiets efterforskning involverer således ofte forsøg på at trænge ind i kriminelle sociotekniske netværk ved at indrullere og trække information ud af dem (Berry 2018). I Danmark har politiets forsøg på at stække og fange budservicesælgerne ofte centreret sig om mobiltelefonerne. En grund til dette er, at sælgernes brug af mobiltelefoner efterlader elektroniske og/eller digitale spor. En anden er, at dansk politi, ligesom deres kollegaer i England (Spicer 2019), har opdaget, at budservicesælgernes salgstelefonnummer også fungerer som deres brand i forhold til kunderne, og at sælgerne derfor er tilbageholdne med at skifte salgsnummer for ofte. Set fra politiets side udgør sælgernes mobiltelefon(nummer) derfor et potentielt svagt led, de kan udnytte til efterforskning.

I dag er en væsentlig del af betjentenes traditionelle overvågningsarbejde uddelegeret til teknologiske stedfortrædere (Latour 1994) i form af teknologiske sporings- og aflytningsanordninger og dataservere, der kontinuerligt registrerer og opsamler data om borgernes telefon- og internetadfærd. I forsøget på at kortlægge en sælgers færden eller en kurerbils rute kan politiet eksempelvis gøre brug af pejlesendere (GPS), der placeres udvendigt på en mistænkt persons bil 
(Institut for Menneskerettigheder 2016), eller de kan udnytte retsplejelovens $\S$ 791a, stk. $5,{ }^{3}$ som giver politiet mulighed for at foretage teleobservation, det vil sige indhente oplysninger fra teleselskaberne om, hvilke telemaster en mistænkt persons telefon har været i kontakt med. I de tilfælde, hvor politiet kan sandsynliggøre, at en kriminel aktivitet antager en særlig grov eller organiseret karakter, giver retsplejelovens $\S 780^{3}$ politiet mulighed for at aflytte en mistænkt persons mobiltelefon, aflæse SMS-beskeder og internetbaseret kommunikation og rumaflytte kurerbilen (Lentz 2017). Som del af dette kan politiet eksempelvis udnytte smartphonens indbyggede internetforbindelse og GPS til at overvåge en mistænkt persons færden og kommunikation. Muligheden for at indrullere budservicesælgeres mobiltelefoner og elektroniske korrespondancer i et „overvågningsassemblage“" (Haggerty \& Ericson 2000) spiller i dag en central rolle i politiets forsøg på at optrevle sælger-køber-forbindelser, kortlægge de involverede parters roller og beregne salgsniveauet, hvilket senere kan bruges som dokumentation i udmålingen af købernes bødestraf og sælgernes fængselsstraf (Søndberg 2014; Søgaard 2016; Abildgaard 2018). Som det foregående antyder, „praktiseres“ budservicesælgeres mobiltelefon i dag gennem flere forskellige og sameksisterende aktørnetværk, der hver producerer multiple versioner (Law 1999; Mol 2002) af telefonen. Mens salgstelefonen i sælger-køber-aktørnetværket artikuleres som et kommercielt passagepunkt for handel med stoffer, artikuleres salgstelefonen i relationen til politiet som et potentielt svagt led, der indgår i politiets produktion af arrestationer og (fængsels)sanktioner.

De to versioner af telefonen er ikke klart adskilte, men derimod karakteriseret af fraktale, det vil sige delvist krydsende, forbindelser (Mol 2002), hvilket for sælgerne imidlertid udgør et væsentligt problem, da det potentielt kan sende dem i fængsel. Sælgernes ,praktisering“ af salgstelefonen som et potentielt svagt led kommer særligt til udtryk i deres løbende forsøg på at „hugge netværket over“ (Strathern 1996), hvilket her vil sige deres forsøg på at blokere eller begrænse de potentielle forbindelser mellem deres salgstelefon og politiets overvågningsassemblage. Forskning har vist, at en af måderne, nogle stofsælgere gør dette på, er ved at engagere sig i et teknologisk våbenkapløb med politiet, hvilket involverer, at de flytter deres kommunikation med kunderne fra traditionelle mobiltelefoner og SMS'er til mere teknologisk avancerede apps som Wickr og Signal, der kan downloades på smartphones (Moyle et al. 2019; Demant et al. 2019). Disse apps har end-to-end-kryptering, hvilket betyder, at såvel afsender som modtager har en krypteringsnøgle, der bruges til at afkode beskeden, mens beskeden for alle andre ligner volapyk. Herudover har appsene enten en indbygget eller en tilvalgsfunktion, hvor beskederne slettes efter et bestemt tidsrum, hvilket gør det svært for politiet at få adgang til dem. En anden måde, som stadig benyttes 
af mange stofsælgere i Danmark, er at gå teknologisk „old school“ (Søgaard et al. 2019). Som eksempel på dette fortalte de sælgere, vi interviewede, at de havde mindst to mobiltelefoner: en smartphone med internetforbindelse til private samtaler og en meget simpel mobiltelefon, ofte af mærket Nokia, uden internet, GPS og Bluetooth til at kommunikere med stofkøberne. Sidstnævnte blev ofte omtalt som enten en „røgtelefon“ (hvis de solgte cannabis) eller en „,coketelefon" (hvis de solgte kokain og andre stoffer). Ifølge sælgerne er billige og simple Nokia-telefoner mere sikre end smartphones, da de er sværere for politiet at infiltrere og spore:

[Gamle Nokia-telefoner] kan ikke overvåges. De [politiet] kan ikke spore den, fordi den har ingen internet (Anas).

Ud over at anvende simple telefoner, som ofte er købt uden abonnement og betalt kontant, forsøgte sælgerne også at minimere risikoen fra politiet ved altid at bruge taletidskort, der kan købes og bruges anonymt:

Jeg har egentlig to telefoner. Jeg har mit private telefonnummer, som jeg har her. Så har jeg en anden telefon [røgtelefon], som jeg har et nummer, hvor jeg egentlig bare køber taletid til. Til folk, der ikke skal have mit privatnummer. Så kan de bare ringe til mit andet nummer (Celal).

Hvis sælgerne fornemmer, at et bestemt nummer er ved at blive „,varmt“, skifter de taletidskort. For sælgerne handler det dog om at finde den rette balance mellem at skifte nummer for at undgå politiet og beholde et nummer for at være tilgængelig for kunderne. Hver gang en sælger skifter nummer, risikerer han nemlig at miste kunder. Brugen af såkaldte „,burner-telefoner“, det vil sige billige mobiltelefoner med uregistrerede simkort, gør det ikke blot svært for politiet at finde ud af, hvilke numre stofsælgerne anvender, men også svært at opspore, hvem der gemmer sig bag de anonyme taletidskort. Fra tid til anden lykkes det dog politiet at identificere personen bag en salgstelefon. Det kan ske ved, at en stofsælger ved en fejltagelse kommer til at sætte et simkort, der er registreret i hans rigtige navn, i en burner-salgstelefon, som overvåges af politiet. Da alle telefoner har et unikt identifikationsnummer (IMEI), og fordi teleselskaberne skal registrere alle simkort, der sidder i en given telefon, vil en sådan fejl betyde, at politiet nu kan koble salgstelefonen med en navngiven person. Som Berry (2018) har beskrevet i sit studie fra England, kan stofsælgere imidlertid også i nogle tilfælde vende politiets overvågning af deres mobiltelefoner til en fordel. Hvis sælgerne har mistanke om, at en bestemt telefon bliver overvåget, kan de eksempelvis efterlade den hjemme og derved skabe sig et digitalt alibi, mens de ordner deres forretninger ude i byen. Ovennævnte giver således både et ind- 
blik i, hvordan salgstelefonen qua dens teknologiske kapacitet til at indgå i en mangfoldighed af konstant ekspanderende forbindelser ofte ,praktiseres“ som et potentielt svagt led i relationen til politiet, samt et indblik i nogle af de metoder, sælgerne anvender til at blokere og undergrave politiets indsamling af elektronisk og/eller digital information om deres kriminelle aktiviteter.

\section{Relationen til andre kriminelle: en vare og et middel til fjendtlig markedsovertagelse}

Brugen af mobiltelefoner og udbredelsen af budservice har ikke kun betydning for måden, stoffer sælges og distribueres på. Det har også skabt en situation, hvor salgstelefoner og deres porteføljer af stofkunder i dag er blevet en handelsvare, der kan sælges og købes på det illegale marked.

Interviewene viste, at et af de centrale mål for mange budservicesælgere er over tid at få opbygget et stort netværk af kunder, der alle ringer til netop deres telefon(nummer), når de ønsker at købe stoffer. Da røg- og coketelefoner, eller mere præcist deres simkort, er det primære kontaktpunkt for et udvidet netværk af kunder, har de i sig selv også fået stor økonomisk værdi:

Folk her i området starter med at sælge narko som 14-årige. De starter i det små, og så opgraderer de den [telefonen]. Større og større. Hvis du starter en telefon som 14-årig, og så pludselig er du 28, og hvis du har solgt med den telefon hele tiden, og du har knoklet for det, så har den mange, rigtig mange kunder. Så er der mange penge i den. Så er den guld værd (Hamsa).

Interviewene viste, at salgstelefoner og deres portefølje af kunder sommetider handles mellem budsælgere for mange penge (se også Søgaard et al. 2019). Stofsælgeren Mehdi forklarede eksempelvis følgende:

Jeg har bare en lille telefon, men jeg kender en herude, der har en telefon, som han lige er blevet tilbudt 200.000 for. 200.000 for sin telefon, jeg sværger. Tænk, hvis du har en telefon til 200.000. Og den telefon til 200.000, den kan lige lave 5000 pr. dag. Så hvor meget er det?

Prisen på en salgstelefon varierer og afhænger af, hvor stort et indtægtspotentiale et specifikt simkort menes at have. For en potentiel „køber“ kan det være svært at vide, hvor indbringende et bestemt simkort vil være i fremtiden. Sælgerne har derfor udviklet en relativt standardiseret procedure, som skal hjælpe potentielle „købere“ og „sælgere“ af et simkort til at nå til enighed om en fair pris. Proceduren består i, at personen, som ønsker at købe et simkort, tilbringer en uge eller to sammen med sælgeren. 
[Hvis jeg skal købe en salgstelefon], så går jeg rundt med personen i en uges tid. Sover med ham, drikker med ham, spiser med ham. Jeg er hele tiden sammen med ham. Så kan jeg se, om telefonen kan lave to lapper, 1000, 500, eller 20.000 kroner. Hvor meget den er værd? Så sidder jeg og regner. Hvis den kan lave så meget, så vil jeg gerne gi’ så meget. Det er det (Mehdi).

Ovenstående er interessant, fordi det viser, hvordan salgstelefoner, deres brand og deres porteføljer af stofkunder til tider artikuleres som en handelsvare i relationen mellem kriminelle budservicesælgere. I relationen mellem kriminelle budservicesælgere artikuleres salgstelefonen imidlertid også som et middel til fjendtlig markedsovertagelse.

Meget forskning har vist, at kriminelles kamp om ejerskabet over traditionelle stofmarkeder ofte handler om kontrollen over bestemte geografiske salgssteder som eksempelvis et gadehøjne (Eck 1994). I takt med at det illegale stofmarked er blevet mere teknologiseret og ,mobiltelefoniseret“, er sælgernes telefoner også blevet centrale mål for kriminelle, der ønsker at erobre markedsandele - nu ved at stjæle deres konkurrenters telefonbaserede kundelister- og netværk. Som et eksempel på dette forklarede sælgeren Salim, at selv om han normalt havde et godt og fredeligt forhold til de andre budservicesælgere i sit område, var han til stadighed bekymret over, om nogle af hans konkurrenter kunne finde på at prøve at ødelægge eller overtage hans forretning ved at stjæle hans salgstelefon:

Vi siger aldrig, hvor meget vores telefoner laver. Kommer der en og spørger mig, så lyver jeg. Så siger jeg bare: 'Den ringer kun én gang om ugen' eller 'Det er ikke så meget, som det var før'. Selv om den virkelig kører godt. Fordi hvis folk begynder at få ondt i røven, så kan de godt finde på at overfalde dig, selv om de har kaldt dig brormand, og tage din telefon. Eller han lejer to personer til at overfalde dig og stjæle din telefon (Salim).

Salim forklarede ydermere, at hvis en person stjal en anden persons salgstelefon, betød det som regel ikke, at „tyven“ blot overtog salgsnummeret, der tilhørte den stjålne telefon. Selv om det kunne være fristende at køre videre med et stjålet salgsnummer, der allerede har en vis brandværdi, er der også en betydelig risiko ved det. Ifølge Salim ville personen, der var blevet bestjålet, sommetider forsøge at hævne sig ved at lægge en fælde, hvor han ringede til det stjålne salgsnummer og foregav at være en kunde, som ønskede at få stoffer leveret. Når kurerbilen ankom, ville den bestjålne sælger og til tider en medsvoren stå klar til at overfalde tyven og, hvis det var et bud, måske tvinge ham til at opgive navnet på tyven:

[Hvis én stjæler mine kunder], så ringer jeg til én [en kriminel, der erhverver sig ved at sælge sine evner til vold] og siger til ham: 'Prøv lige at ringe til det her nummer og sig, du lige gerne vil ha' noget'. Så ringer han, og [når tyven kommer 
med stofferne], så får han BARE en omgang, fordi han har stjålet mine kunder (Salim).

Frem for at arbejde videre med et stjålet salgsnummer vil personer, der har stjålet en anden sælgers salgstelefon, ofte forsøge at omdirigere den stjålne telefons kundebase til et nyt nummer:

Du beholder bare telefonen og simkortet [det stjålne], for der er alle kontakter i, så ved du, hvad dine kunder hedder, jo. Du skifter nummer. Bare skriver ud: 'Hej, jeg har lige fået nyt nummer.' Så er du allerede i gang (Nasser).

For at minimere skaden ved et eventuelt tyveri af deres salgstelefon valgte nogle sælgere at have deres kunders numre gemt på et stykke papir. Ulempen ved dette er imidlertid, at hvis politiet laver en ransagning og finder dette papir, kan det bruges som bevis i en retssag. Flere var derfor tilbageholdende med at have nedskrevne kundenumre liggende.

Salgstelefonen er ikke kun genstand for tyveri fra individuelle konkurrenter. Forsøg på at tiltvinge sig kontrol over andres salgstelefoner spiller også en central rolle, når mere organiserede bander forsøger at lave en fjendtlig markedsovertagelse af hele områder. Som tidligere nævnt strakte vores dataindsamling sig over seks måneder. Midt i denne periode opstod der en situation, hvor en meget organiseret bande, her kaldet V-20, med base i København forsøgte at overtage store dele af stofmarkedet i Telborg. Mens det område, hvor vi lavede dataindsamling, traditionelt havde været domineret af individuelle stofsælgere og mindre sælgerteams, fik truslen fra den udefrakommende bande den konsekvens, at mange af de normalt adskilte sælgerteams nu begyndte at arbejde sammen i en større enhed, som både politiet og nogle af sælgerne beskrev som en bande, her kaldet TB. Over de følgende måneder udspillede der sig en voldsom konflikt om ejerskabet over Telborgs stofmarked med natlige skyderier, knivstik og sporadiske slåskampe rundtomkring i byen. Mens en del af konflikten havde en klar territoriel karakter, handlede en væsentlig del af kampen også om ejerskabet over salgstelefonerne og deres kundeporteføljer:

Jamaal: Altså TB-banden lukker, når V-20 lukker [forsvinder]. Så er der ikke længere nogen, der går rundt med pistoler eller andre våben. Lidt som det var for et halvt år siden. V-20, de vil jo gerne stjæle folks telefoner. Ved du, hvad en dodo er? En røgtelefon. Dem fra København kalder den for en dodo. Så siger de: 'Kom med din dodo, kom med din narkotelefon.' Der er nogle af dem, der har været efter mig, fordi der er én, som har fortalt dem, at min telefon kører godt. De ved, jeg er fra Sølvtoften [område i Telborg], og hvordan jeg ser ud, men de ved ikke, hvad jeg hedder. Jeg så dem til Open By Night for et par uger siden, én havde en V-20-trøje på. De løb efter mig på hovedgaden. Så jeg løb mod Bones 
[restaurant] og sprang ind i en taxa.

Forsker: Men de fik ikke fat i dig?

Jamaal: Nej nej, det gjorde de ikke, men nu har jeg lejet min telefon ud til en kammerat, så jeg ikke mister den. Der er alt for mange problemer nu. Så jeg har givet den til én, som ingen kender, som lejer den.

Ovenstående er interessant, fordi det viser, hvordan kampen om det teknologiserede stofmarked ikke længere kun handler om kontrollen over bestemte territorier og salgssteder, men i lige så høj grad om kontrollen over salgstelefonerne, da man derved får kontrol over kundenetværkene.

\section{Konklusion}

I modsætning til folkelige forståelser, som ofte antager, at stofmarkedet er en monolitisk entitet, har meget nyere forskning peget på, at stofmarkeder varierer både vertikalt mellem markedsniveauer (top-, mellem- og detailniveau) og inden for det samme markedsniveau (Coomber 2015). I denne artikel har jeg zoomet ind på ét specifikt detailmarked, som man kan kalde for det telefonbaserede budservicemarked for illegale rusmidler. Selv om brugen af mobiltelefoner i stofhandel ikke er ny (Curtis et al. 2002), kan de sidste årtiers ekspansion af det telefonbaserede budservicemarked i Danmark alligevel ses som et eksempel på, hvordan udbredelsen af digitale og telebaserede kommunikationsteknologier i stigende grad forandrer måden, illegale rusmidler handles og distribueres på. På denne baggrund har artiklen argumenteret for, at specifikke stofmarkeder med fordel kan forstås som sociotekniske netværk, der formes og forandres gennem samspillet mellem sociale og teknologiske processer. Den konkrete udformning af forskellige sociotekniske stofmarkeder vil naturligvis variere lokalt og nationalt, og der er derfor et præsent behov for empiriske studier af de specifikke teknosociale sammenfletninger og deres indflydelse på måden, stofhandler og markedspraksisser artikuleres.

Denne artikel har foreslået, at et ANT-perspektiv kan være analytisk anvendeligt i denne proces. Mere specifikt har jeg vist, hvordan et fokus på sælgeres salgstelefon og de forskellige måder, denne bliver ,praktiseret“ på, kan fungere som en prisme, hvorigennem vi kan fă indblik i de multiple og fraktale sociotekniske netværk og praksisser, som i dag giver form til det mobiltelefonbaserede budservicemarked for illegale rusmidler i Danmark. Analysen har vist, hvordan opbygningen af en succesfuld budserviceforretning i høj grad er afhængig af sælgernes evne til at konstruere et specifikt telefonnummer som et attraktivt passagepunkt for potentielle købere på jagt efter illegale stoffer. Analysen har også vist, hvordan forskelligartede sociotekniske netværksformationer og praksisser 
skaber forskellige, men også delvis forbundne versioner af mobiltelefonen, og hvordan der til stadighed foregår en kamp mellem politiets forsøg på at indrullere salgstelefonen i et overvågningsnetværk og sælgernes forsøg på at blokere eller begrænse de forbindelser, deres telefon indgår i. Et af de mest interessante fund er, at det telefonbaserede budservicemarked for illegale stoffer er kendetegnet ved, at sælgernes salgstelefoner og simkort ikke kun har brugsværdi, men også stor økonomisk udvekslingsværdi, da de fungerer som det teknologiske knudepunkt for større kundeporteføljer. Sagt på en anden måde: Fordi relationen mellem købere og sælgere er medieret af telefonteknologien og et specifikt telefonnummer, er stofbrugerne ikke længere blot konfigureret som kunder, det vil sige som personer, der køber en vare og servicer. I det telefonmedierede illegale stofmarked er forbrugerne - deres kontaktinformationer, deres opmærksomhed og deres oparbejdede loyalitet over for et bestemt telefonnummer/sælgerbrand også selv blevet vareliggjorte. Vareliggørelse af forbrugeren er naturligvis ikke et unikt karaktertræk ved det illegale stofmarked. Tværtimod kan man sige, at den stigende vareliggørelse af forbrugeren i det telefonbaserede illegale stofmarked på mange måder reflekterer centrale tendenser i den legale kapitalisme, hvor især det ekspanderende digitale marked i dag er domineret af firmaer som Google og Facebook, hvis forretningsmodel er baseret på at akkumulere og videresælge forbrugernes informationer og opmærksomhed til andre firmaer, som ønsker at markedsføre og sælge deres produkter (Kang \& McAllister 2011). Et yderligere lighedstræk er, at forbrugerne på både det legitime digitale marked og på det illegale marked for stoffer ofte er uvidende om, at de nu er blevet varer, som handles mellem kommercielle aktører. Naturligvis er der også væsentlige forskelle mellem legale og illegale markeder. En af de centrale forskelle er, at mens førstnævnte er karakteriseret ved statslig regulering og formelle klageinstanser, er sidstnævnte kendetegnet ved et fravær af samme. På det illegale budservicemarked kommer det blandt andet til udtryk ved, at sælgernes salgstelefoner ikke blot praktiseres som en handelsvare, men også som objekter for tyveri og midler til fjendtlig markedsovertagelse. Det har skabt en situation, hvor voldelige konflikter om ejerskabet over det illegale stofmarked ikke længere kun handler om kontrollen over bestemte territorier og salgssteder (for eksempel et gadehjørne) som i traditionelt stofsalg (Eck 1994), men i lige så høj grad om kontrollen med salgstelefonerne: Kontrollerer man salgstelefonerne, kontrollerer man kundenetværkene og derved også væsentlige dele af markedet.

Man skal naturligvis være påpasselig med ikke at drage for generaliserede konklusioner om det danske budservicemarked for illegale rusmidler på baggrund af et trods alt relativt lille studie som ovennævnte. Analysens fund kan eksempelvis være influeret af, at alle de deltagende stofsælgere er mænd med etnisk minori- 
tetsbaggrund. Det kan være, at brugen af „old school“-telefoner er mere udbredt blandt budservicesælgere med etnisk minoritetsbaggrund end blandt etnisk danske budservicesælgere, som måske i højere grad gør brug af krypterede smartphoneapps i kommunikationen med kunderne. På den anden side har Barendregt et al. (2006) på baggrund af en undersøgelse af illegale budservicemarkeder i Holland konkluderet, at disse markeder var domineret af sælgere med etnisk minoritetsbaggrund. Hvis det også gør sig gældende i Danmark, giver ovenstående analyse formentlig et relativt retvisende billede af den generelle situation. At undersøge mere indgående, i hvilket opfang det danske budservicemarked for illegale rusmidler er etnisk og teknologisk differentieret, er en opgave for fremtidig forskning.

\section{Noter}

1. Begrebet „,enacted“ forklares nærmere i afsnittet „Analytisk ramme“.

2. Navnet på det større forskningsprojekt er „Perceptions of Procedural Justice among Ethnic Minority Youth“. Projektet ledes af professorerne Geoffrey Hunt og Torsten Kolind og har deltagelse af adjunkt Mie Birk Haller, ph.d.-studerende Mads Madsen og lektor Thomas Friis Søgaard, Center for Rusmiddelforskning, Aarhus Universitet. Projektet er finansieret af Danmarks Frie Forskningsfond.

3. Retsplejeloven. Lov om rettens pleje. https://danskelove.dk/retsplejeloven. Besøgt 25.5.2019

\section{Litteratur}

Abildgaard, Amalie

201825 sigtede for besiddelse af hash. Telefon afslørede køberkartotek. Bt.dk 26.9.

Barendregt, Cas, Agnes van der Poel \& Dike van de Mheen

2006 The Rise of the Mobile Phone in the Hard Drug Scene of Rotterdam. Journal of

Psychoactive Drugs 38(1):77-87. DOI: 10.1080/02791072.2006.10399830.

Barratt, Monica J. \& Judith Aldridge

2016 Everything You Always Wanted to Know About Drug Cryptomarkets* (*But

Were Afraid to Ask). International Journal of Drug Policy 35:1-6. DOI: 10.1016/ j.drugpo.2016.07.005.

Berry, Mark

2018 Technology and Organised Crime in the Smart City. An Ethnographic Study of the Illicit Drug Trade. City, Territory and Architecture 5(16):1-11. DOI: 10.1186/ s40410-018-0091-7.

Callon, Michel

1986 Some Elements of a Sociology of Translation. Domestication of the Scallops and the Fishermen of St Brieuc Bay. In: J. Law (ed.): Power, Action and Belief. Pp. 196-233. London: Routledge. 
Coomber, Ross

2015 A Tale of Two Cities. Understanding Differences in Levels of Heroin/Crack Market-Related Violence. A Two City Comparison. Criminal Justice Review 40(1):7-31. DOI: 10.1177/0734016814565817.

Curtis, Ric, Travis Wendel \& Barry Spunt

2002 We Deliver. The Gentrification of Drug Markets on Manhattan's Lower East Side.

Final report. Rockville, MD: U.S. Department of Justice.

Dahlin, Ulrik

2015 Autonom, pusher, mentor. Et portræt af Søren Lerche. København: Gyldendal.

Demant, Jakob, Silje Anderdal Bakken, Atte Oksanen \& Helgi Gunnlaugsson

2019 Drug Dealing on Facebook, Snapchat and Instagram. A Qualitative Analysis of Novel Drug Markets in the Nordic Countries. Drug and Alcohol Review 38(4): 377-85. DOI: 10.1111/dar.12932.

Eck, John

1994 Drug Markets and Drug Places. A Case-Control Study of the Spatial Structure of Illicit Drug Dealing. College Park: University of Maryland.

EMCDDA: European Monitoring Centre for Drugs and Drug Addiction

2018 Recent Changes in Europe's Cocaine Market. Results from an EMCDDA

Trendspotter Study. Luxembourg: Publications Office of the European Union.

Frank, Vibeke Asmussen

2008 Danish Drug Policy. Shifting from Liberalism to Repression. Drugs and Alcohol Today 8(2):26-33. DOI:10.1108/17459265200800015.

Gad, Christopher \& Casper Bruun Jensen

2007 Post-ANT. I: C.B. Jensen, P. Lauritsen \& F. Olesen (red.): Introduktion til STS. Science, Technology, Society. Side 93-118. København: Hans Reitzels Forlag.

Global Drug Survey

2018 https://www.globaldrugsurvey.com/gds-2018. Læst 23.5.2019.

Gustavsen, Rikke \& Carsten Ellegaard

2013 Halvdelen af befolkningen må være skæv. Jyllands-Posten 4.10.

Haggerty, Kevin D. \& Richard V. Ericson

2000 The Surveillant Assemblage. British Journal of Sociology 51(4):605-22. DOI: $10.1080 / 00071310020015280$.

Haller, Mie Birk, Randi Solhjell, Elsa Saarikkomäki, Torsten Kolind \& Geoffrey Hunt 2020 Minor Harassments. Ethnic Minority Youth in the Nordic Countries and Their Perceptions of the Police. Criminology \& Criminal Justice 20(1):3-20. DOI: $10.1177 / 1748895818800744$.

Indenrigs- og Sundhedsministeriet

2003 Kampen mod narko. Handlingsplan mod narkotikamisbrug. København: Regeringen.

Institut for Menneskerettigheder

2016 Magtanvendelse. 2015-2016. København: Danmarks Nationale Menneskerettighedsinstitution. 
Jensen, Torben Elgaard

2005 Aktør-netværks-teori - Latours, Callons og Laws materielle semiotik.

I: A. Esmark, C.B. Laustsen \& N.Å. Andersen (red.): Socialkonstruktivistiske analysestrategier. Side 185-209. Roskilde: Roskilde Universitetsforlag.

Kang, Hyunjin \& Matthew P. McAllister

2011 Selling You and Your Clicks. Examining the Audience Commodification of

Google. Communication, Capitalism \& Critique 9(2):141-53. DOI: 10.31269/

triplec.v9i2.255.

Latour, Bruno

1994 On Technical Mediation. Common Knowledge 3(2):29-64. DOI: 10.31269/ triplec.v9i2.255.

2005 Reassembling the Social. An Introduction to Actor Network-Theory. New York: Oxford University Press.

Law, John

1999 After ANT. Complexity, Naming and Topology. The Sociological Review 47(1):

1-14. DOI: 10.1111/j.1467-954X.1999.tb03479.x.

Lentz, Lene W.

2017 Retsplejelovens regulering af politiets adgang til teledata. Tidsskrift for

Kriminalret 10:1240-52. DOI: ART20170011-TFK.

May, Tiggey \& Mike Hough

2004 Drug Markets and Distribution Systems. Addiction Research \& Theory 12(6):549-

63. DOI: $10.1080 / 16066350412331323119$.

Mol, Annemarie

2002 Cutting Surgeons, Walking Patients. Some Complexities Involved in Comparing. In: J. Law \& A. Mol. (eds): Complexities. Pp. 218-57. Durham: Duke University Press.

Moyle, Leah, Andrew Childs, Ross Coomber \& Monica J. Barratt

2019 \#Drugsforsale. An Exploration of the Use of Social Media and Encrypted

Messaging Apps to Supply and Access Drugs. International Journal of Drug Policy

63:101-10. DOI: 10.1016/j.drugpo.2018.08.005.

Salinas, Mike

2018 The Unusual Suspects. An Educated, Legitimately Employed Drug Dealing

Network. International Criminal Justice Review 28(3):226-42. DOI: 10.1177/

1057567717745583 .

Spicer, Jack

2019 "That's Their Brand, Their Business". How Police Officers Are Interpreting

County Lines. Policing and Society 29(8):873-86. DOI: 10.1080/

10439463.2018.1445742.

Strathern, Marilyn

1996 Cutting the Network. The Journal of the Royal Anthropological Institute 2(3):517-

35. DOI: $10.2307 / 3034901$.

Strauss, Anselm \& Juliet M. Corbin

1997 Grounded Theory in Practice. London: Sage.

Søgaard, Jan

201622 års fængsel til „De Hvide Bude“. Ekstra Bladet 17.5.

2018 De Hvide Bude leverede kokain til kunder døgnet rundt. Ekstra Bladet.dk 3.10. 
Søgaard, Thomas Friis, Torsten Kolind, Mie Birk Haller \& Geoffrey Hunt

2019 Ring and Bring Drug Services. Delivery Dealing and the Social Life of a Drug Phone. International Journal of Drug Policy 69:8-15. DOI: 10.1016/ j.drugpo.2019.02.003.

Søgaard, Thomas Friis

2018 De ringer - vi bringer. Et studie af cannabislevering til døren. STOF. Tidsskrift for stofmisbrugsområdet 31:12-17. DOI: 2441435922.

2019a Buyer Motives for Sourcing Illegal Drugs from "Drop-Off" Delivery Dealers. In: Z. Kaló, J. Tieberghien \& D. J. Korf (eds): Explanations for Drug Use and Drug Dealing in Social Drug Research. Pp. 123-36. Lengerich: Pabst Science Publishers.

2019b Drop-Off Drug Distribution. Why Users Choose to Source Illegal Drugs from Delivery Dealers. Nordic Journal of Criminology 20(2):213-22. DOI: 10.1080/ 2578983X.2019.1667676.

Søndberg, Astrid

2014 Ring af „Hvide bude“ anholdt. 400 kokain-købere afsløret. TV2.dk 4.12. 